\title{
Analisis Penerapan Metode Profile Matching untuk Mengukur Kesenjangan Digital (Studi Kasus: RSUD Panembahan Senopati Bantul)
}

\author{
Analysis of the Application of the Profile Matching Method to Measure the \\ Digital Gap (Case Study: RSUD Panembahan Senopati Bantul)
}

\author{
Wahyu Ciptaningrum*1, Ema Utami ${ }^{2}$, Eko Pramono ${ }^{3}$ \\ 1,2,3 Magister Teknik Informatika Universitas Amikom Yogyakarta \\ E-mail: *1wahyu.ciptaningrum@students.amikom.ac.id, ${ }^{2}$ ema.u@amikom.ac.id, \\ 3eko.p@amikom.ac.id
}

\begin{abstract}
Abstrak
Kesenjangan digital memiliki definisi tentang perbedaan kemampuan individu atau sekelompok masyarakat dalam mengikuti perkembangan teknologi informasi dan komunikasi. Salah satu Organisasi Perangkat Daerah di Kabupaten Bantul yang telah menerapkan egovernment ialah Rumah Sakit Umum Daerah (RSUD) Panembahan Senopati. Pemanfaatan TIK pada RSUD adalah sebagai pendukung pengambilan keputusan di bidang keuangan dan pelayanan. Dalam pemanfaatan TIK tersebut, terdapat beberapa permasalahan seperti kurangnya sumber daya manusia yang IT minded, sehingga dibutuhkan pengukuran kesenjangan digital. Penelitian ini menggunakan metode statistika nonparametrik untuk mengetahui kesenjangan digital di lingkungan instansi RSUD tersebut signifikan atau tidak. Selanjutnya, variabel-variabel kesenjangan digital diukur kemudian diberi perankingan menggunakan metode profile matching. Berdasarkan hasil analisis dan pembahasan tentang pengukuran kesenjangan digital pada pegawai RSUD Panembahan Senopati Kabupaten Bantul yang dilakukan, dapat diambil kesimpulan bahwa perankingan tingkat kesenjangan digital pada pegawai RSUD Panembahan Senopati kabupaten Bantul dimulai dari yang paling tinggi ialah pada aspek penggunaan e-government, yaitu dengan indeks 4,2 disusul oleh penggunaan internet dengan indeks sebesar 4,1 dan yang memiliki kesenjangan paling rendah ialah aspek penggunaan internet dengan indeks sebesar 1,2.
\end{abstract}

Kata Kunci-Kesenjangan Digital, Profile Matching, statistik

\begin{abstract}
Digital divide has definition about the difference between a person or a society to follow the information technology. One of Government's Organization in Bantul Regency that has implemented e-government is Panembahan Senopati Regional General Hospital. The use of ICT in the house of Panembahan Senopati General Hospital is become a supporter of decision making in the financial and service fields. In the implementation ICT, there are problems that the lack of human resources that are IT minded, so we need to measure the digital divide. This research uses nonparametric statistical methods to determine digital gap in the hospital environment is significant or not. Next, the digital gap variables are measured then ranked using the profile matching method. Based on the results of the analysis and discussion of digital gap measurement at Panembahan Senopati Hospital employees, it can be concluded that the ranking of the digital gap level at Panembahan Senopati Hospital staffs starts from the highest is in the aspect of egovernment use, with the index 4.2 and followed by the use of internet with an index of 4.1 and lowest gap was the aspect of internet use with an index 1.2.
\end{abstract}

Keywords-3-5 Digital Divide, Profile Matching, Statistics. 


\section{PENDAHULUAN}

Kesenjangan digital memiliki definisi ketidakseimbangan atau terdapatnya jurang pemisah antara sekelompok atau individu yang memiliki kemampuan untuk mengikuti perkembangan teknologi informasi dan yang tidak mempunyai hal tersebut [1]. Faktor ini yang mempengaruhi kesenjangan digital ialah sosial ekonomi, teknologi, dan budaya. Faktor-faktor lain yang turut memengaruhi peristiwa kesenjangan digital antara lain demografi usia, pendidikan, pekerjaan, dan status sosial. Peristiwa kesenjangan digital tidak hanya terjadi pada sekelompok masyarakat di suatu lingkungan tempat tinggal, tetapi juga terjadi di kalangan instansi pemerintahan.

Rumah Sakit Umum Daerah (RSUD) Panembahan Senopati merupakan salah satu Organisasi Perangkat Daerah di Kabupaten Bantul yang telah menerapkan pemanfaatan Teknologi Informasi Komunikasi (TIK). RSUD Panembahan Senopati mempunyai tugas untuk mendukung penyelenggaraan pemerintah daerah. Kedudukan Rumah Sakit Daerah di Kabupaten Bantul ialah langsung di bawah bupati dan bertanggung jawab melalui sekretariat daerah. Pemimpin rumah sakit daerah di Kabupaten Bantul ialah seorang direktur.

Tugas utama RSUD Panembahan Senopati yaitu berkaitan dengan pelaksanaan penyusunan dan kebijakan daerah di bidang pelayanan kesehatan. Pelaksanaan kebijakan daerah bidang pelayanan kesehatan tentu saja berhubungan dengan pemanfaatan TIK. Pemanfaatan TIK pada rumah RSUD Panembahan Senopati berdasarkan misi "Meningkatkan ketersediaan sarana prasarana yang berkualitas" [2]. Tugas dari misi tersebut antara lain ialah sebagai pendukung pengambilan keputusan di bidang keuangan dan pelayanan. Penerapan pemanfaatan TIK memerlukan keselasaran dengan misi rumah sakit. Dalam pelaksanaan yang berhubungan dengan pemanfaatan TIK tersebut, tentu saja terdapat permasalahan dan kendala. Permasalahan tersebut termasuk kurangnya sumber daya manusia yang IT minded, sehingga dibutuhkan pengukuran kesenjangan digital, faktor-faktor apa saja yang memiliki gap yang menonjol, serta rekomendasi seperti apa yang cocok untuk diterapkan di instansi RSUD Panembahan Senopati untuk mengurangi kesenjangan digital. Untuk itu, peneliti bermaksud untuk melakukan penelitian berupa pengukuran kesenjangan digital yang terjadi di lingkungan rumah sakit tersebut. Selain itu, penelitian ini diharapkan dapat memberikan rekomedasi saran yang tepat untuk keselarasan hubungan antara lingkungan sumber daya manusia dalam hal ini pegawai dengan pemanfaatan teknologi informasi supaya tercipta peningkatan mutu berkelanjutan dalam pelayanan kesehatan, serta sarana dan prasarana yang berkualitas sesuai dengan misi RSUD Panembahan Senopati Kabupaten Bantul.

Penelitian yang digunakan untuk mengukur kesenjangan digital salah satunya ialah milik Konstantin A. Pantserev [3]. Penelitian tersebut menggunakan responden penelitian penduduk di Negara-negara di benua Afrika dari berbagai kalangan sehingga cakupan penelitiannya sangat luas. Sementara itu, metode yang digunakan ialah konsep kesenjangan digital secara teoritis dan juga berdasarkan pendapat-pendapat dari masyarakat dan pemerintah setempat. Hasil penelitian tersebut ialah meskipun ada sejumlah hambatan yang secara total menghambat pembangunan masyarakat informasi di wilayah ini, hambatan yang paling penting ialah sebagai pengembangan kapasitas manusia yang artinya masyarakat belum menyadari keunggulan teknologi informasi, perkembangan konten digital lokal di Afrika dan memopulerkan Bahasa Afrika di internet, penerapan prinsip dasar konsep e-government, serta penjelasan undang-undang informasi efektif.

Carolyn Seton dan Raina Mason, melakukan penelitian mengenai mendeskripsikan antara user interface design sebagai bagian dari Digital Age Project dengan masyarakat lanjut usia sebagai penggunanya. Hasil yang didapat dari penelitian tersebut ialah standard UI guidelines sangatlah penting untuk diikuti ketika mendesain interface sebuah aplikasi untuk pengguna yang masih bersifat pemula yang usianya di atas 55 tahun [4].

Penelitian lain sebelumnya berkaitan dengan dampak kesenjangan digital terhadap aplikasi sistem informasi e-voting di Negara Afrika oleh Mohammad Kamel [5]. Penelitian tersebut memperkenalkan kerangka kerja (framework) yang diusulkan untuk membagi faktor kesenjangan digital. Kerangka kerja ini bertujuan untuk mengeksplorasi dampak faktor-faktor 
kesenjangan digital terhadap kesediaan pemilih untuk menggunakan sistem e-voting. Faktorfaktor tersebuat ialah usia, Pendidikan, pendapatan, dan penggunaan internet. Dengan dampak faktor kesenjangan digital ini yang diartikulasikan sehubungan dengan e-voting, pemerintah Yordania akan berada dalam posisi untuk mempertimbangkan sentrisitas warga negara dalam tahap implementasi sistem e-voting. Pemerintah Yordania harus memanfaatkan sistem e-voting sebagai pendekatan untuk meningkatkan interaksi-interaksi dan komunikasi dengan warga Yordania.

Kesenjangan digital ternyata berdampak terhadap penyandang disabilitas. MA Hussain dan S. Iqbal [6], mengusulkan model teknologi yang selaras dengan hukum hak asasi penyandang cacat bagi negara-negara baik yang telah menerapkan maupun belum menerapkan hukum dan bimbingan untuk hak-hak disabilitas. Penelitian tersebut menunjukkan usulan model teknologi berupa pembangunan framework dan kode praktik yang bertujuan memberikan bantuan bagi penyandang cacat, menyediakan layanan spesifik untuk menjaga kebutuhan penyandang cacat, dan sebagainya.

Husni Muharram Ritonga [7], melakukan penelitian analisis aplikasi penilaian terhadap calon debitur yang mengajukan pinjaman di suatu bank. Pada penelitian tersebut terdapat parameter-parameter yang harus diberikan dan parameter-parameter yang menjadi pertimbangan. Menurut penelitian tersebut, metode profile matcing merupakan metode yang baik untuk melihat calon debitur yang memenuhi syarat untuk menerima pinjaman. Sehingga, analis dapat mengatur nilai target yang diinginkan.

Metode profile matching dapat digunakan untuk mengukur kesenjangan produktivitas karyawan berdasarkan penelitian Hasrul Anwar [8]. Penelitian tersebut menguji tingkat kinerja karyawan dengan menghitung beberapa faktor yang mempengaruhi kinerja karyawan. Untuk menentukan nilai prestasi diperlukan metode yang cepat dan akurat. Metode profile matching adalah metode yang benar digunakan dalam penilaian karyawan perusahaan. Metode ini dapat memberikan gambaran di mana karyawan tersebut layak disimpan dan mana yang tidak layak. Manfaat yang diberikan sangat membantu untuk menjadi referensi pemilik perusahaan untuk meningkatkan reputasi perusahaan.

Berdasarkan uraian tersebut di atas, peneliti mengusulkan penelitian berupa pengukuran kesenjangan digital yang lingkupnya meliputi satu instansi. Penelitian-penelitian terdahulu yang membahas pengukuran kesenjangan lebih menitikberatkan pada metode kuantitatif kemudian ditarik kesimpulan angka atau persentase faktor-faktor yang memengaruhi kesenjangan digital. Untuk itu, peneliti mengusulkan penerapan metode profile matching karena setelah disimpulkan seberapa signifikan kesenjangan digital pada suatu instansi, perlu dilakukan perankingan untuk setiap faktor yang berpengaruh serta hasil penelitian tersebut dapat menunjukkan aspek informatika.

\section{METODE PENELITIAN}

Penelitian ini menggunakan metode statistika nonparametrik dengan pendekatan kuantitatif dalam pengolahan data dan pengukuran indeks kesenjangan digital. Setelah diperoleh indeks kesenjangan digital, maka dilakukan perangkingan menggunakan metode profile matching. Indeks kesenjangan digital yang akan dilakukan penelitian berdasarkan standardisasi dari indikator Statistical Indicators for Benchmarking the Information Society (SIBIS) [9]. Aspek indikator-indikator tersebut terdiri atas penggunaan komputer, penggunaan internet, dan $e$ government. Alur dari penelitian ini diawali dengan mendapatkan rumusan masalah dengan melakukan studi literature pada penelitian-penelitian yang sudah ada berupa jurnal internasional maupun nasional. Dari penelitian tersebut, diperoleh rumusan masalah serta metode yang tepat untuk digunakan. Alur pengumpulan data dijabarkan pada Gambar 1. 
Citec Journal, Vol. 7, No. 1, Januari 2020

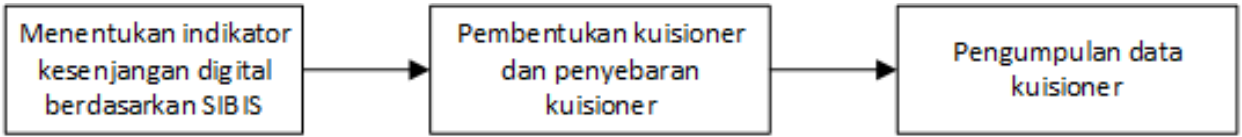

Gambar 1. Pengumpulan Data

Aspek / indikator kesenjangan digital ditentukan berdasarkan framework berdasarkan Statistical Indicators for Benchmarking the Information Society. Aspek-apek kesenjangan digital ialah sebagai berikut:

1. Kesenjangan digital dari pengguna computer

2. Kesenjangan digital dari pengguna internet

3. Kesenjangan digital dari aspek e-government

4. Demografi, yang terdiri atas usia karyawan dan pendidikan

Selanjutnya, kuesioner disebar kepada responden dengan sampel yang digunakan ialah 34 pegawai. Selanjutnya, kuesioner disebar kepada responden dengan sampel yang digunakan ialah 34 pegawai. Alur analisis akan dijlaskan pada Gambar 2.

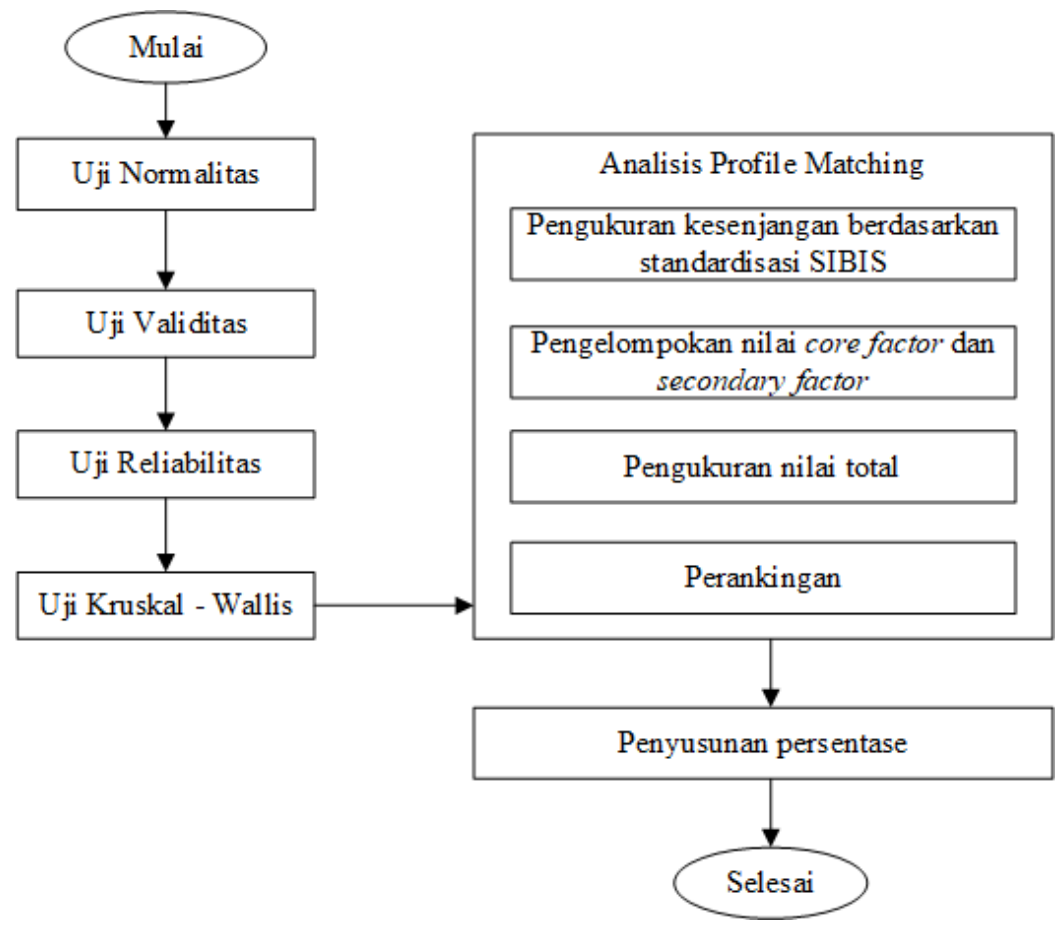

Gambar 2. Analisis Data

Uji validitas dan reabilitas dilakukan sebelum melakukan perhitungan analisis gap. Pengelompokan bobot nilai gap yang terjadi antara kesenjangan digital dari pengguna komputer, kesenjangan digital dari pengguna internet, dan aspek e-government terhadap demografi kemudian dihitung menggunakan metode profile matching.

Pada analisis profile matching, pengukuran gap/kesenjangan mengacu pada standardisasi SIBIS pada bagian benchmarking value.

1. Aspek penggunaan komputer dengan benchmarking value sebesar 3 .

2. Aspek penggunaan internet dengan benchmarking value sebesar 3 .

3. Aspek e-governmet dengan benchmarking value sebesar 3.

Langkah setelah pengukuran gap/kesenjangan atau pembobotan ialah penentuan core factor dan secondary factor. Nilai core factor dan secondary factor diambil pada aspek demografi yaitu latar belakang pendidikan dan usia. Pada penelitian ini, aspek yang menjadi core factor ialah latar belakang pendidikan. Aspek yang menjadi secondary factor ialah aspek umur/usia. 
Langkah setelah penentuan core factor dan secondary factor ialah perhitungan nilai total berdasarkan kedua nilai tersebut. Pada penelitian ini, nilai total didapat dari penjumlahan $60 \%$ dari core factor (latar belakang pendidikan) dan $40 \%$ dari secondary factor (usia).

Langkah terakhir dari analisis profile matching ialah perankingan. Pada aspek penggunaan komputer, penggunaan internet, dan e-government akan diurutkan berdasarkan indeks kesenjangan digital. Setelah selesai melakukan perankingan, indeks kesenjangan digital tersebut akan dikonversi ke dalam bentuk persen. Berdasarkan hasil persentase tersebut akan diketahui gap yang menonjol, dalam arti bagian yang memiliki kesenjangan digital dengan persentase paling tinggi. Dari hasil tersebut akan disusun rekomendasi untuk memberikan masukan kepada pihak RSUD Panembahan Senopati Kabupaten Bantul.

\subsection{Metode Pengumpulan Data}

Penelitian menggunakan tiga metode pengumpulan data sebagai berikut:

1. Menggunakan proses wawancara, yaitu perbincangan yang dilakukan oleh pengelola bagian TI, staff bagian struktural, dan petugas pelayanan untuk mendapatkan informasi dan mengumpulkan data primer yang digunakan sebagai acuan penelitian.

2. Membuat angket/kuesioner, dengan cara mengajukan pertanyaan tertulis kepada responden. Dalam hal ini responden adalah beberapa staff bagian struktural dan petugas pelayanan. Kuesioner pengukuran kesenjangan digital telah disusun berdasarkan indikator SIBIS [10], dan telah diterjemahkan ke dalam Bahasa Indonesia. Angket yang telah diterjemahkan ke dalam Bahasa Indonesia tersebut terdiri atas 24 pertanyaan yang dibagi berdasarkan aspekaspek penggunaan komputer, penggunaan internet, dan e-government [11].

3. Teknik sampel digunakan dalam pengumpulan data responden. Cara menggunakan teknik sampel adalah dengan memilih secara acak suatu objek dari objek keseluruhan [12]. Sampel yang digunakan pada penelitian ini ialah pegawai Rumah Sakit Umum Daerah Panembahan Senopati Kabupaten Bantul. Untuk menentukan jumlah sampel yang akan diambil, penelitian ini menggunakan rumus Slovin [13]. Berdasarkan rumus Slong, diketahui populasi $=31$, dan tingkat error $=0.05$. Maka $n=31.075$ dibulatkan menjadi 32. Jumlah populasi 32 pegawai dan tingkat error yang digunakan adalah 0.05. Jadi sampel yang digunakan ialah 34 pegawai.

\subsection{Metode Analisis Data}

Pada tahapan analisis data, angket/kuesioner yang disebar diberi skor dengan kategori skala likert. Skor jawaban berdasarkan skala likert dibagi menjadi 5 kategori yaitu:

$$
\begin{aligned}
& \text { Skor }=5, \text { untuk jawaban sangat setuju } \\
& \text { Skor }=4, \text { untuk jawaban setuju } \\
& \text { Skor }=3 \text {, untuk jawaban kurang setuju } \\
& \text { Skor }=2 \text {, untuk jawaban tidak setuju } \\
& \text { Skor }=1 \text {, untuk jawaban sangat tidak setuju }
\end{aligned}
$$

Data yang telah diperoleh dari jawaban angket/kuesioner kemudian dilakukan analisis. Berdasarkan jumlah responden yang kurang dari 50, maka metode analisis yang dilakukan terhadap data tersebut ialah statistika nonparametrik [14]. Tahapan analisis yang pertama ialah normalisasi data. Pada metode statistika nonparametrik, data telah dianggap normal namun alangkah baiknya apabila dilakukan normalisasi. Normalisasi yang digunakan dalam penelitian ini ialah dengan pendekatan Kolmogorov-smirnov [15]. Tahapan analisis yang kedua ialah menguji validitas data dengan metode pendekatan yang sama saitu Kolmogorov-smirnov. Setelah uji validitas yang hasilnya diketahui valid atau tidaknya data, dilakukan tahapan analisis yang ketiga yaitu uji reliabilitas. Berdasarkan pengujian reliabilitas, maka dilakukan analisis analisis profile matching dengan gap yang telah ada stardardisasi dari SIBIS. Analisis profile matching dilakukan untuk mengetahui rangking dari aspek-aspek kesenjangan digital. 
Citec Journal, Vol. 7, No. 1, Januari 2020

\section{HASIL DAN PEMBAHASAN}

\subsection{Uji Normalitas Kuesioner}

Uji normalitas kuesioner dilakukan untuk mengetahui kemungkinan hasil hipotesis yang dirumuskan sebelum angket/kuesioner dibagi kepada responden. Pada penelitian ini, dibagikan kuesioner kepada 34 responden/sampel. Uji normalitas yang digunakan ialah dengan metode Kolmogorov-smirnov karena jumlah responden yang kurang dari 200. Hasil uji normalitas ditunjukkan pada Gambar 3, Gambar 4, dan Gambar 5.

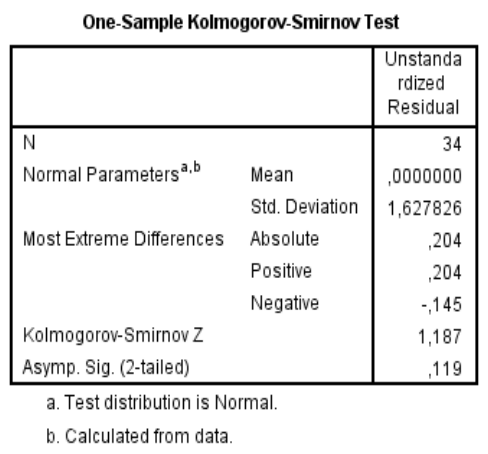

Gambar 3. Uji Normalitas Aspek 1

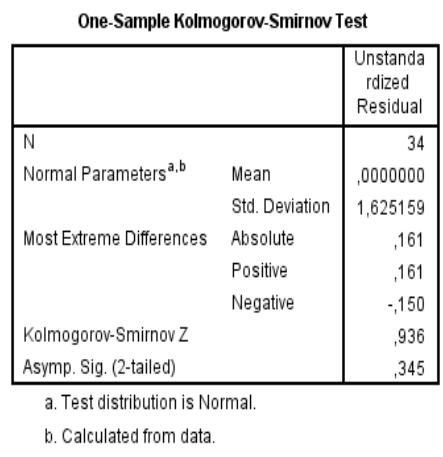

Gambar 4. Uji Normalitas Aspek 2

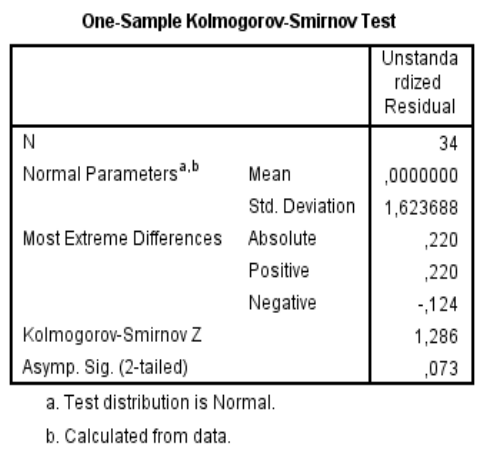

Gambar 5. Uji Normalitas Aspek 3

Pada Gambar 3, Gambar 4, dan Gambar 5, terlihat bahwa nilai asymp. Sig pada ketiga aspek kesenjangan digital sebesar 0,119, 0,345, dan 0,073 sementara standar error minimal ialah 0,05 . Ini berarti nilai asymp. Sig lebih besar dari 0,05 sehigga telah memenuhi syarat data terdistribusi normal. Sehingga data tersebut dinyatakan terdistribusi normal.

\subsection{Uji Validitas Kuesioner}

Uji validitas kuesioner yang digunakan pada penelitian ini ialah uji $\mathrm{r}$ dengan alasan jumlah responden yang tidak mencapai angka 200. Uji validitas terlihat pada Gambar 6 .

\begin{tabular}{|c|c|c|c|c|c|}
\hline \multicolumn{6}{|c|}{ Correlations } \\
\hline & & $\begin{array}{c}\text { total_penggu } \\
\text { naankompute } \\
r\end{array}$ & $\begin{array}{l}\text { total_penggu } \\
\text { naaninternet }\end{array}$ & $\begin{array}{c}\text { total_egovern } \\
\text { ment }\end{array}$ & $\begin{array}{c}\text { total_per_res } \\
\text { ponden }\end{array}$ \\
\hline \multirow{3}{*}{$\begin{array}{l}\text { total_penggunaankomput } \\
\text { er }\end{array}$} & Pearson Correlation & 1 &,- 187 &, 072 &, 237 \\
\hline & Sig. (2-tailed) & & ,289 & 687 & 177 \\
\hline & N & 34 & 34 & 34 & 34 \\
\hline \multirow[t]{3}{*}{ total_penggunaaninternet } & Pearson Correlation &,- 187 & 1 & .323 & $806^{\prime \prime}$ \\
\hline & Sig. (2-tailed) & 289 & &, 063 &, 000 \\
\hline & N & 34 & 34 & 34 & 34 \\
\hline \multirow[t]{3}{*}{ total_egovernment } & Pearson Correlation & .072 & .323 & 1 & $.726^{* 2}$ \\
\hline & Sig. (2-tailed) &, 687 &, 063 & &, 000 \\
\hline & N & 34 & 34 & 34 & 34 \\
\hline \multirow[t]{3}{*}{ total_per_responden } & Pearson Correlation &, 237 & $806^{2 \pi}$ & .726 & 1 \\
\hline & Sig. (2-tailed) & .177 &, 000 &, 000 & \\
\hline & $N$ & 34 & 34 & 34 & 34 \\
\hline
\end{tabular}

**. Correlation is significant at the 0.01 level (2-tailed).

Gambar 6. Uji Validitas Kuesioner 
Berdasarkan analisis korelasi pearson, terlihat bahwa hasil analisis pada aspek penggunaan komputer sebesar 0,237. Hasil analisis pada aspek penggunaan internet sebesar 0,806. Sementara itu, aspek e-government sebesar 0,726. Hasil analisis pearson dari ketiga aspek tersebut lebih besar dari 0,05 sehingga data dinyatakan valid.

\subsection{Uji Reliabilitas Kuesioner}

Uji reliabilitas kuesioner yang digunakan pada penelitian ini ialah uji cronbach alpha. Uji reliabilitas dengan analisis cronbach alpa disajikan pada Gambar 7.

Reliability Statistics

\begin{tabular}{|r|r|}
\hline $\begin{array}{c}\text { Cronbach's } \\
\text { Alpha }\end{array}$ & N of Items \\
\hline, 696 & 25 \\
\hline
\end{tabular}

Gambar 7. Uji Reliabilitas Kuesioner

Syarat untuk memenuhi hasil uji nalisis cronbach alpha ialah lebih dari 0, 05. Hasil uji reliabilitas pada penelitian ini ialah 0,696 yang lebih dari 0,05 sehingga memenuhi syarat uji reliabilitas.

\subsection{Analisis Data}

Terpenuhinya syarat uji normalitas, validitas, dan reliabilitas dapat melanjutkan penelitian ini pada tahap analisa data. Yang dianalisis pada penelitian ini ialah apakah ada kesenjangan digital, persentase indeks kesenjangan digital berdasarkan aspek penggunaan komputer, penggunaan internet, dan e-government, serta peringkat indeks kesenjangan digital berdasarkan ketiga aspek tersebut.

\subsubsection{Analisis Kruskal Wallis}

Jumlah responden yang kurang dari 200 atau kisaran 30. Penelitian ini digunakan untuk menguji kesenjangan digital/perbedaan dengan sampel yang saling tidak terikat. kuesioner yang digunakan pada penelitian ini berskala likert, sehingga data yang diperoleh mempunyai skala ordinal. Berdasarkan uraian tersebut, maka pengujian yang digunakan ialah statistika nonparametrik dengan analisis Kruskal Wallis. Tabel 1 menjelaskan analisis kruskal wallis.

Tabel 1. Uji Analisis Kruskal Wallis

\begin{tabular}{|l|l|l|l|}
\hline Grup dan Aspek & Kruskal-Wallis H & Df & Asymp. Sig (H0) \\
\hline umur dan penggunaan komputer & 5,013 & 4 & 0,286 \\
\hline umur dan total penggunaan internet & 7,7 & 4 & 0,103 \\
\hline umur dan e-government & 2,301 & 4 & 0,681 \\
\hline pendidikan dan penggunaan komputer & 2,918 & 3 & 0,404 \\
\hline pendidikan dan penggunaan internet & 7,323 & 3 & 0,062 \\
\hline pendidikan dan egovernment & 3,849 & 3 & 0,078 \\
\hline
\end{tabular}

Dari Gambar 6, diperoleh pengujian antara grup (umur, pendidikan) dan aspek (penggunaan komputer, penggunaan internet, dan e-government). Pada grup umur pengguna diperoleh asymp. Sig sebesar 0,286 untuk aspek penggunaan komputer, 0,103 untuk aspek penggunaan internet, dan 0, 681 untuk aspek e-government. Sementara itu, pada grup pendidikan pengguna computer diperoleh asymp. Sig sebesar 0,404 untuk aspek penggunaan komputer, asymp. Sig sebesar 0,062 untuk aspek penggunaan internet, dan asymp. Sig sebesar 0,078 untuk aspek e-government. 
Hipotesis dari pengujian ini ialah:

H0: ada terjadi kesenjangan digital/perbedaan antara grup dan aspek

H1: tidak terjadi kesenjangan digital antara grup dan aspek.

H1 yang dijadikan standar dari penelitian ini ialah 0,05. Dengan demikian, dapat dilihat bahwa semua hasil H0 melebihi H1 (H0>H1), sehingga hipotesis H0 diterima. Dengan demikian, terjadi atau ada kesenjangan digital antara grup umur, grup pendidikan, dengan aspek-aspek penggunaan komputer, penggunaan internet, dan e-government.

\subsubsection{Analisis Profile Matching}

Analisis profile matching dilakukan berdasarkan hasil kuesioner yang diisi oleh ke-34 responden dan hasil hipotesis yang telah dianalisis berdasarkan uji statistika kruskal-wallis. Data yang dianalisis berdasarkan hasil dari uji Kruskal-Wallis terdapat pada Tabel 2.

Tabel 2. Uji Kruskal Wallis dengan pembulatan angka

\begin{tabular}{|l|r|r|}
\hline Aspek & Umur & Pendidikan \\
\hline penggunaan komputer & 5 & 3 \\
\hline penggunaan internet & 8 & 7 \\
\hline e-government & 2 & 4 \\
\hline
\end{tabular}

Terlihat pada Tabel 2, hasil uji Kruskal-Wallis yang digunakan mengacu pada Tabel 1 dengan pembulatan nol angka di belakang koma. Langkah selanjutnya yang dilakukan ialah perhitungan gap. Pada pengukuran kesenjangan digital jika berdasarkan SIBIS, standar pengukuran ialah 3. Langkah pengujian setelah pembulatan angka berdasarkan uji kruskal-Wallis ialah mengukur kesenjangan/gap seperti pada pada Tabel 3.

Tabel 3. Pengukuran gap

\begin{tabular}{|l|r|r|}
\hline Group dan Aspek & Umur & Pendidikan \\
\hline penggunaan komputer & 5 & 3 \\
\hline penggunaan internet & 8 & 7 \\
\hline e-government & 2 & 4 \\
\hline standar pengukuran SIBIS & 3 & 3 \\
\hline gap penggunaan komputer & 2 & 0 \\
\hline gap penggunaan internet & 5 & 4 \\
\hline gap e-government & -1 & 1 \\
\hline
\end{tabular}

Pada Tabel 3, gap penggunaa komputer jika dilihat dari sisi umur berjumlah 2 yang berarti kelebihan 2 tingkat dari standardisasi, sedangkan dari sisi Pendidikan berjumlah 0 yang berarti memenuhi standar. Gap penggunaan internet mempunyai hasil 5 pada sisi umur yang artinya kelebihan 5 tingkat dari standardisasi, untuk hasil dari sisi Pendidikan ialah 4 artinya kelebihan 4 tingkat dari standardisasi. Gap e-government dari sisi umur berjumlah -1 yang artinya kekurangan 1 tingkat dari standardisasi sedangkan dari sisi Pendidikan berjumlah1 yang artinya kelebihan 1 tingkat dari standardisasi. Langkah setelah pengukuran kesenjangan/gap ialah perankingan seperti pada Tabel 4.

Tabel 4. Perankingan

\begin{tabular}{|l|r|r|r|}
\hline Aspek & Umur & Pendidikan & Ranking \\
\hline Penggunaan komputer & 3,5 & 5 & 4,1 \\
\hline Penggunaan Internet & 1 & 1,5 & 1,2 \\
\hline E-Government & 4 & 4,5 & 4,2 \\
\hline
\end{tabular}


Pada Tabel 4, keputusan perankingan ditentukan berdasarkan ranking yang didapat. Semakin tinggi jumlah yang didapat, maka indeks kesenjangan digital semakin tinggi. Kesenjangan paling tinggi ada pada aspek e-government dengan indeks 4,2 disusul dengan aspek pengunaan komputer yaitu 4,1 dan yang paling rendah ialah aspek penggunaan internet dengan indeks 1,2. Semakin tinggi indeks kesenjangan digital, maka kesenjangan/perbedaan semakin tinggi [16].

\subsubsection{Usulan Perbaikan}

Hasil pengukuran kesenjangan digital di lingkungan Rumah Sakit Umum Daerah Panembahan Senopati Kabupaten Bantul menunjukkan bahwa tidak ada perbedaan/kesenjangan yang signifikan antara teknologi informasi dan komunikasi yang sudah terkelola dengan pengelola dalam hal ini pegawai-pegawai di instansi tersebut.

Pada aspek penggunaan komputer, responden merasa telah memahami penggunaan komputer secara umum dibuktikan dengan hasil pengukuran pada aspek ini memperoleh indeks kesenjangan digital teritnggi. Hanya saja, akan ditemukan ketidakefisienan maka dari itu diperlukan aplikasi-aplikasi software yang tersedia versi desktop dan mobile. Sistem yang dikelola oleh pihak Rumah Sakit Umum Pusat Dr. Sardjito bisa dijadikan acuan dalam pengembangan software.

Pada aspek penggunaan internet, jika berdasarkan kuesioner yang dibagikan maka dapat ditarik kesimpulan bahwa penggunaan internet di tempat kerja telah berfungsi dengan baik. Diperlukan pemeliharaan agar infrastruktur akses internet dapat bertahan dengan baik.

Pada aspek e-government, pegawai dalam hal ini responden telah sadar akan pentinganya e-government di lingkungan instansi. Untuk itu, diperlukan aplikasi atau software yang lebih user friendly untuk meningkatkan kinerja pelayanan.

\section{KESIMPULAN}

Berdasarkan hasil analisis dan pembahasan tentang pengukuran kesenjangan digital pada pegawai RSUD Panembahan Senopati Kabupaten Bantul yang dilakukan, dapat diambil kesimpulan sebagai berikut:

1. Ketiga aspek kesenjangan digital yaitu penggunaan komputer, penggunaan internet, dan egovernment memiliki tingkat persentase yang berbeda-beda.

2. Tingkat kesenjangan digital pada pegawai RSUD Panembahan Senopati Kabupaten Bantul jika dilihat dari aspek perilaku penggunaan komputer berada pada indeks 4,1.

3. Tingkat kesenjangan digital pada pegawai RSUD Panembahan Senopati Kabupaten Bantul pada aspek penggunaan internet ialah 1,2. Indeks pada aspek ini merupakan yang terkecil daripada kedua aspek lainnya.

4. Tingkat kesenjangan digital pada pegawai RSUD Kabupaten Bantul berdasarkan aspek pengetahuan tentang e-government ialah sebesar 4,2. Indeks pada aspek ini memiliki kesenjangan/perbedaan yang paling tinggi jika dibandingkan dengan aspek penggunaan komputer dan penggunaan internet.

5. Tingkat kesenjangan digital paling tinggi ialah pada aspek pengetahuan tentang egovernment.

\section{SARAN}

Dari hasil penelitian, pembahasan, dan kesimpulan di atas, adapun saran-saran yang dapat disampaikan peneliti berkenaan dengan hasil penelitian ini ialah sebagai berikut:

1. Pihak organisasi responden agar mengadakan bimbingan teknis yang mengarah ke pemikiran tentang teknologi informasi terkait pemanfaatan teknologi yang digunakan di organisasi. 
2. Berdasarkan hasil penelitian, pembahasan, dan kesimpulan, kesenjangan digital terhadap aspek e-governmet termasuk yang indeksnya paling tinggi, sehingga diperlukan solusi untuk memberikan pengetahuan yang lebih mendalam kepada pengelola aplikasi sistem informasi manajemen yang ada di lingkungan instansi responden.

3. Berdasarkan hasil penelitian, pembahasan, dan kesimpulan, kesenjangan digital terhadap aspek penggunaan internet memiliki indeks yang paling rendah, namun pemahaman mengenai internet tetap dipertahankan kepada responden.

4. Dengan diketahuinya persentase tingkat kesenjangan digital pada aspek-aspek penggunaan komputer, penggunaan internet, dan e-government, maka diharapkan dapat menjadi evaluasi pada pihak responden sehingga kinerja karyawan dapat ditingkatkan.

5. Sebagai solusi awal dari tindak lanjut pada aspek kesenjangan digital yang paling tinggi tingkatannya yaitu pada penggunaan komputer, saat ini telah banyak perangkat yang bisa digunakan sebagai pembantu computer seperti smartphone. Diharapkan pada pihak responden ke depannya untuk melibatkan smartphone untuk pemanfaatan TIK di lingkungan rumah sakit, seperti membuat software disposisi dengan versi web dan mobile.

6. Penelitian selanjutnya agar dapat dilakukan dengan menggunakan instrumen yang berbeda.

\section{DAFTAR PUSTAKA}

[1] Gabriel, C. D. P. B., 2017, Pengukuran Kesenjangan Digital Masyarakat Di Kabupaten Lembata, Tesis, Magister Teknik Informatika, Universitas Atma Jaya Yogyakarta, Yogyakarta

[2] RSUDPS, https://rsudps.bantulkab.go.id/hal/tujuan-sasaran-dan-kebijakan

[3] Panteserev, K. A., 2016, Digital Divide as an Obstacle of the Independent of the States of the Sub-Saharan Africa, ICEGOV '15-16: 9th International Conference on Theory and Practice of Electronic Governance, New York, 1 - 3 Maret

[4] Seton, C., Mason, R., 2016, Decreasing the Digital Divide-Analysis the UI Requirements of Older Australians, ACSW '16: Australasian Computer Science Week, Canbera, 2 - 5 Februari.

[5] Alomari, M. K., 2016, Digital Divide Impact on E-Voting Adoption in Middle Eastern Country, 2016 11th International Conference for Internet Technology and Secured Transactions (ICITST), Barcelona, 5-7 Desember

[6] Hussain, M. A., Ahsan, K., Iqbal, S., Nadeem, A., 2017, Disability and Digital Divide: Bridging the Gap Through Archimate Approach, Pakistan Journal of Science, No. 4, Vol 68, Hal. 426 - 431.

[7] Ritonga, H. M., Hasibuan, H. A., Siahaan, A. P., 2017, Credit Assessment in Determining the Feasibility of Debtors Using Profile Matching, International Journal of Business and Management Invention, No. 1, Vol. 6

[8] Hasibuan, H. A., Purba, R. Br., Siahaan, A. P. U., 2016, Productivity Assessment (Performance, Motivation, and Job Training) Using Profile Matching, SSRG International Journal of Economics andManagement Studies (SSRG-IJEMS), No. 6, Vol. 3, Hal. 73 - 77

[9] The University of Applied Sciences Solothurn Northwest Switzerland, SIBIS New eEroupe Indikator Handbook, Vol. 4, Hal. 10-14, http://sibiseu.org/files/SIBIS_Indicator_Handbook.pdf

[10] The University of Applied Sciences Solothurn Northwest Switzerland, SIBIS New eEroupe Indikator Handbook, Vol. 4, 78-139, http://sibiseu.org/files/SIBIS_Indicator_Handbook.pdf 
[11] Tyas, D. L., 2016, Pengukuran Kesenjangan Digital Masyarakat Di Kota Pekalongan, Tesis, Magister Teknik Informatika, Universitas Atma Jaya Yogyakarta, Yogyakarta

[12] Setiawan, Nugraha, 2007, Penentuan Ukuran Memakai Rumus Slovin dan Tabel KrejcieMorgan: Telaah dan Konsep Aplikasinya, http://pustaka.unpad.ac.id/wpcontent/uploads/2009/03/penentuan_ukuran_sampel_memakai_rumus_slovin.pdf, diakses tanggal 2 Desember 2019.

[13] Asari, A., Toloh, B. H., Sangari, J. R. R., 2018, Development Of Community Based Ecotourism In Bahoi Village, West Likupang District, North Minahasa Regency, Jurnal Ilmiah Platax, No. 1, Vol. 6, Hal. 29 - 41

[14] Herlina, V., 2019, Panduan Praktis Mengolah Data Kuesioner Menggunakan SPSS, Elex Media Komputindo, Jakarta.

[15] Santoso, S., 2017, Menguasai SPSS Versi 25, Elex Media Komputindo, Jakarta.

[16] Hidayatullah, S., 2013, Pengukuran Kesenjangan Digital Di Dinas Perkebunan dan Peternakan Kabupaten Tapanuli Selatan, Tesis, Magister Chief Information Officer, Universitas Negeri Padang, Padang. 